\title{
Epidermoid cyst: highlights on diagnosis and magnetic resonance imaging features
}

\section{Cisto epidermóide: processo de diagnóstico e características das imagens por ressonância magnética}

\begin{abstract}
Purpose: Epidermoid and dermoid cysts are extremely rare developmental cysts of a benign nature, which may occur anywhere in the body, although about $7 \%$ are found in the head and neck. This article reports a clinical case of a patient who had an epidermoid cyst and its magnetic resonance imaging (MRI) features.

Case report: This case discusses an epidermoid cyst in a 36 -year-old woman complaining about speech difficulty. Clinical examination revealed an extensive swelling on the floor of the mouth. MRI findings showed a cystic homogenous lesion located underneath the mylohyoid muscle which was removed by surgery. Histological examination of the mass confirmed the diagnosis of an epidermoid cyst.

Conclusion: We concluded that MRI was considered useful for a more accurate diagnosis prior to treatment.
\end{abstract}

Key words: Epidermoid cyst; dermoid cyst; magnetic resonance images; differential diagnosis

\section{Resumo}

Proposta: Cistos epidermóide e dermóide são cistos de desenvolvimento extremamente raros, de natureza benigna, que podem ocorrer em qualquer região do corpo e somente $7 \%$ são encontrados na região de cabeça e pescoço. Este artigo apresenta o caso clínico de uma paciente que possuía um cisto epidermóide juntamente com as características das imagens por ressonância magnética.

Descrição do caso: Paciente do gênero feminino, 36 anos, apresentou-se com queixa de dificuldade de fonação e deglutição. $\bigcirc$ exame clínico intrabucal revelou uma extensa tumefação em soalho bucal. As imagens por ressonância magnética indicaram uma lesão de natureza cística, homogênea, de conteúdo sólido e localizada abaixo do músculo milohiódeo. A lesão foi enucleada e encaminhada para exame anatomopatológico, cujo diagnóstico foi compatível com cisto epidermóide.

Conclusão: A imagem por ressonância magnética foi essencial para determinar as características da lesão de acordo com a sua localização anatômica.

Palavras-chave: Cisto epidermóide; cisto dermóide; imagens por ressonância magnética; diagnóstico diferencial.

\author{
Larissa Santana Arantes Elias a \\ Angélica Ferreira Oton-Leite a \\ Clóvis Martins Silva b \\ Rejane Faria Ribeiro-Rotta a \\ Aline Carvalho Batista a \\ Elismauro Francisco de Mendonça ${ }^{\circ}$
}

\begin{abstract}
- Department of Oral Medicine (Oral Pathology), Dental School, Federal University of Goiás, Goiânia, GO, Brazil

b Araújo Jorge Hospital, Association of Cancer Combat of Goiás, Goiânia, GO, Brazil
\end{abstract}

\section{Correspondence:}

Elismauro Francisco de Mendonça

Faculdade de Odontologia da Universidade Federal de Goiás

Primeira Avenida Número 1964, Setor Universitário

Goiânia, GO - Brasil

74605-020

E-mail: elismaur@odonto.ufg.br

Conflict of Interest Statement: The authors state that there are no financial and personal conflicts of interest that could have inappropriately influenced their work.

Copyright: (C) 2010 Elias et al.; licensee EDIPUCRS This is an Open Access article distributed under the terms of the Creative Commons AttributionNoncommercial-No Derivative Works 3.0 Unported License. 


\section{Introduction}

Epidermoid and dermoid cysts are extremely rare developmental cysts of a benign nature, which may occur anywhere in the body, but most predominantly in the ovary and scrotal regions (1-3). Only about $7 \%$ are found in the head and neck $(1,2,4)$. The occurrence of such cysts in the oral cavity is extremely rare, with approximately $1.6 \%$ located in this area $(1,2,4)$. The floor of the mouth is the most commonly affected area, however, these cysts can also be found in the tongue, lips, buccal mucosa and jaw and mandible bones (2-5). Because of the difficulty of making a correct diagnosis of these lesions when using clinical examinations and conventional radiological images, it is recommended that specialized imaging examinations should be used, such as ultrasonography (US), computed tomography (CT) and Magnetic Resonance Imaging (MRI) $(1,2,4-10)$.

We describe a case of a patient who had an epidermoid cyst and discuss features such as age of occurence, anatomic location, differential diagnosis and imaging findings.

\section{Case report}

A 36-year-old female patient was referred to the Head and Neck Division of the Araújo Jorge Hospital (Association of Cancer Combat of Goiás), Goiânia-GO, complaining mainly about "a growth in her mouth that had affected her speech". The patient stated that the lesion had appeared two years ago, was painless, but was causing progressive speech difficulty. During the intrabucal clinical examination, good dental conditions were noted as well as a swelling measuring $5 \times 4 \mathrm{~cm}$, located in the floor of the mouth (Fig. 1a). The initial diagnosis was the possibility of a salivary gland lesion.

To assist with the diagnosis of the lesion, it was decided to request basic complementary examinations including conventional images such as panoramic and total occlusal images of the jaw. MRI was also requested. The results of the hematological and biochemical examinations were normal. Neither the panoramic nor occlusal images made any further contribution to the diagnosis. However, a lesion was detected in the MRI of the maxillofacial regions (Fig. 1d and 1e). It was an ovoid lesion of regular margins with a slightly hyperintense signal on the T1 sequence and a markedly hyperintense signal on the $\mathrm{T} 2$ sequence with no attenuation when fat suppression was used (Fig. $1 \mathrm{~b}$ and $1 \mathrm{c}$ ). The lesion measuring $4.4 \times 3.6 \times 2.9 \mathrm{~cm}$ was located in the floor of the mouth and, after using paramagnetic contrast, presented well defined borders (Fig. 1c). The right submandibular salivary duct presented with sialectasia before its opening. The MR findings were compatible with an epidermoid cyst.

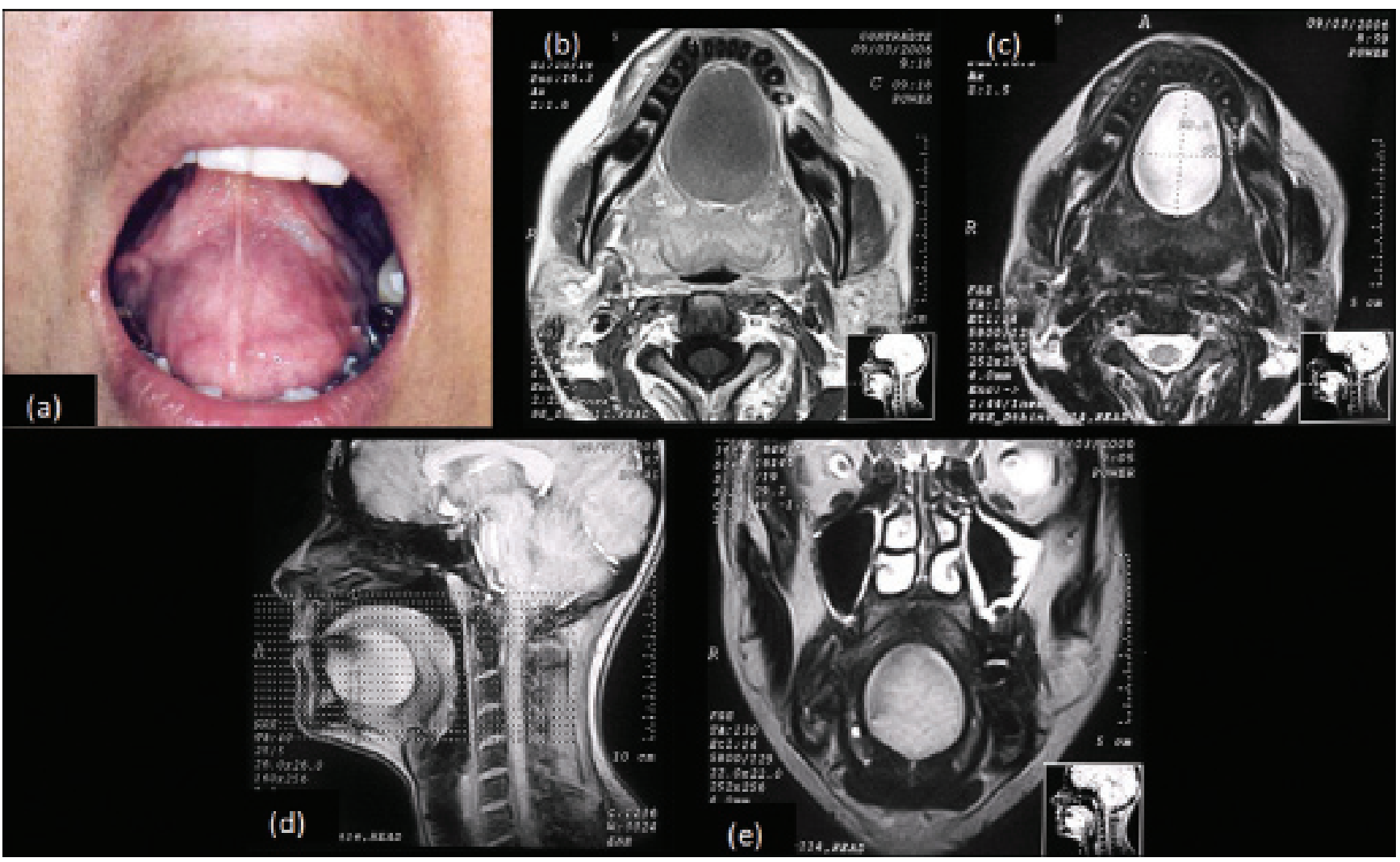

Fig. 1. The clinical and MRI findings. (a) A swelling in the middle of the floor of the mouth. (b) Axial T1-weighted scan with a slightly hyperintense signal; (c) Axial T2-weighted scan with a markedly hyperintense signal with fat suppression; (d) Sagittal T2-weighted scan and (e) Coronal T2-weighted scan showing an ovoid lesion of regular margins. 
On the basis of the clinical and radiographic data the patient underwent general anesthesia to remove the lesion. Aspiratory puncture of the lesion was carried out followed by incision and tecidual divulsion with total enucleation of the cyst. The specimen was sent for anatomopathological examination in which the microscopic aspects confirmed a cystic-type lesion lined with stratified squamous epithelium and filled with keratin (Fig. 2a and 2b). The postoperative period was uneventful (Fig. 3).

\section{Discussion}

The terminology and nomenclature of the epidermoid and dermoid cysts are controversial. The term dermoid is a distinct entity that is normally used to indicate three different types of cyst: the real dermoid, the epidermoid and the teratoma $(3,4,7)$. All dermoid cysts have an epithelial covering, but contain cutaneous annexes, whereas epidermoid cysts do not contain dermic annexes and the covering of the teratoma contains structures whose origins are in the three germinative layers $(1,3,4,5,7)$. Dermoid cysts occur more frequently than epidermoid cysts, in a ratio of 2:1 (2). The current case was considered an epidermoid cyst because it did not present the necessary characteristics to classify it as a dermoid cyst.

The etiology of epidermoid cysts is unknown, but is associated with the presence of remnants of embryonic tissue (ectoderm) during the fusion of the first (mandible) and second (hyoid) branchial arches during the third and fourth intrauterine weeks $(1,4)$.

With regard to location, these cysts can be classified as being located in a median or lateral position $(2,3,4,7)$. Median cysts develop below the lingual brake and between the genioglossal muscle while lateral cysts are located between the genioglossal and mylohyoid muscles (4). Cysts may also be classified according to their position within the muscle, since this influences the therapeutic approach to be adopted. Thus, epidermoid cysts can be located above the geniohyoid and below the genioglossal muscles, curving with the floor of the mouth; they can also be present below the geniohyoid muscle and above the mylohyoid muscle, arching in the submental region, or can be located laterally in the submandibular space above the mylohyoid muscle and to the side of the base of the tongue $(2-4,7)$. In this specific case, the magnetic resonance image showed a median cyst located above the geniohyoid and below the genioglossal muscles, clinically presented as a swelling in the floor of the mouth.

Epidermoid cysts are generally diagnosed between the ages of 15 and 50 , on average at 35 , occurring with the same frequency in both males and females $(3,4)$. Our patient was a 36-year-old, thereby being consistent with the literature. In general, these cysts grow slowly and painlessly and, depending on their size and location, can make it difficult to chewing, swallowing and speaking $(1,3,4)$. Such reports are consistent with the present case since the patient only sought treatment when her speech was impaired.
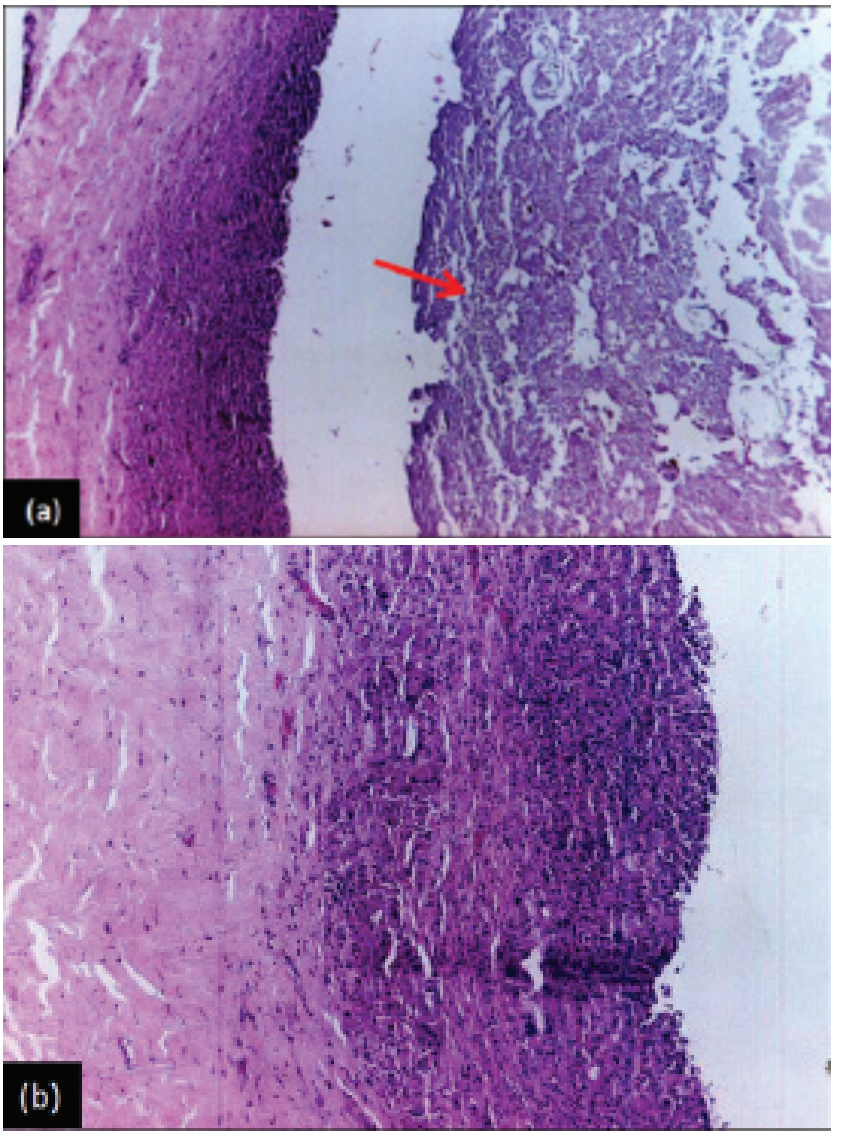

Fig. 2. Epidermoid cyst: histopathological characteristics. (a) Cystic-type lesion lined with stratified squamous epithelium and filled with keratin (red arrow) (hematoxylin-eosin stain; original magnification $5 x(a)$ and $10 x(b))$.

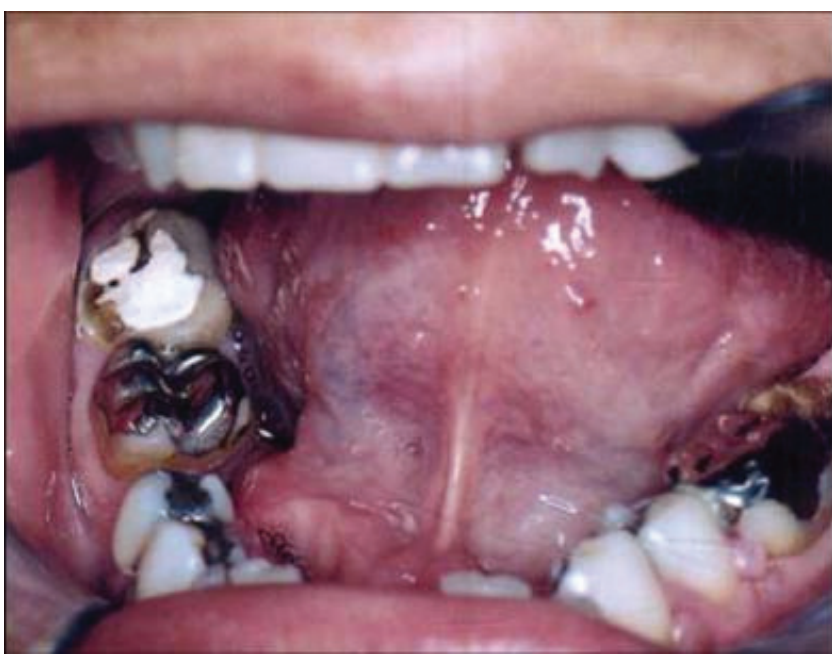

Fig. 3. There were no signs of recurrence at the 2-year follow-up. 
In a differential diagnosis of lesions located in the floor of the mouth, the dermoid, epidermoid, linfoepithelial, and tireoglossac duct cysts must be included as well as neoplasms of the sublingual or minor salivary glands, cystic hygroma and ranula $(1,2,4,5,6,10)$. Because of the difficulty encountered in making a correct diagnosis of these lesions it is recommended that specialized imaging examinations should be used $(1,2,4-10)$.

US is the first choice because of its feasibility, low cost and efficacy (4). Together with MRI it presents better tecidual resolution when compared with computed tomography $(8,9)$. In general, these cysts can be visualized as a well-defined mass with homogenous internal structures and a welloutlined cystic wall $(7,8)$.

Some authors consider MRI superior to other methods, since it shows the exact position, extension and demarcation of dermoid cysts $(2,4,10)$. With this exam, different slices and plans of the region in question can be obtained since the sagittal image is extremely important for the positioning of medial tumors and the diagnosis of benign cystic lesions $(2,4,10)$. With MRI, the epidermoid cyst is described as a cystic mass, which is hypointense in T1-weighted images and hyperintense in T2-weighted images $(5,8,10)$. The intensity of the signal varies according to the ratio of keratin (protein) to cholesterol (lipid) (8). A lipid material shows high intensity on both $\mathrm{T} 1$ and T2-weighted images, whereas a material with keratin shows a low to intermediate intensity on T1-weighted images and intermediate to high intensity on T2-weighted images (8). Considering the large amount of keratin in our case, the signal was low intensity on T1-weighted images and high intensity on T2-weighted images. An epidermoid cyst is typically seen on CT as a well-defined, lobulated mass with hypoattenuation similar to that of lesions containing fluid $(8,11)$.

The treatment to be given to these lesions varies according to the clinical presentation of the cyst and its location (11). It could involve an intraoral or extraoral procedure or a combination of both. Various authors have suggested that an intraoral procedure be undertaken in cases of a sublingual cyst or small cysts while an extraoral procedure would be indicated for those cysts located in the submental, supra-hyoid region, that is, when the submandibular and submental spaces are involved or in cases of large lesions $(2-4,11)$.

Therefore, we conclude that, in the current case of an epidermoid cyst, the MRI exam was of utmost importance in complementing the clinical diagnosis and it could be correlated with the microscopic findings of the lesion, since the epidermoid cyst contained a large amount of keratin providing consistent images in MRI.

\section{References}

1. De Ponte FS, Brunelli A, Marchetti E, Bottini DJ. Sublingual epidermoid cyst. J Craniofac Surg 2002;13:308-10.

2. Fuchshuber S, Grevers G, Issing WJ. Dermoid cyst of the floor of the mouth - a case report. Eur Arch Otorhinolaryngol 2002; 259:60-2.

3. Bataineh AB, Mansour MJ. Extraoral epidermoid cysts. Br J Oral Maxillofac Surg 1997;35:49-51.

4. Kandogan T, Koç M, Vardar E, Selek E, Sezgin O. Sublingual epidermoid cyst: a case report. J Med Case Reports 2007;1: $1-4$.

5. Kim SH, Han MH, Park SW, Chang KH. Radiologic - pathologic correlation of unusual lingual masses: Part I: Congenital lesions/ Part II: Benign and malignant tumors. Korean J Radiol 2001; 2:37-51.

6. Anavi Y, Kaplan I, Calderon S. Lateral neck mass. Oral Surg Oral Med Oral Pathol Oral Radiol Endod 2002;94:536-39.
7. Ariyoshi $Y$, Shimahara M. Magnetic resonance imaging of a submental dermoid cyst: Report of a case. J Oral Maxillofacial Surg 2003;61:507-10.

8. Ariji Y, Gotoh M, Naitoh M, Izumi M, Shimozato K, Kurita K, et al. Magnetic resonance imaging assessment of tumorous lesions in the floor of the mouth: case reports and review of the literature. Oral Radiol 2006:22:18-26.

9. Chikui T, Shimizu M, Goto TK, Nakayama E, Yoshiura K, Kanda S, et al. Interpretation of the origin of a submandibular mass by CT and MRI imaging. Oral Surg Oral Med Oral Pathol Oral Radiol Endod 2004;98:721-29.

10. Potts M, Macleod RI, McLean NR, Chippindale AJ. The value of a magnetic resonance imaging in the assessment of a sublingual epidermoid cyst. Dentomaxillofac Radiol 1992;21:102-4.

11. Fung HS, Wong HN, Lau S, Wong WK, Tang KW. A 50-year-old man with a submental mass. Hong Kong Med J 2008 14:161-2. 